\title{
Identification and Investigation of Subsidence Areas to Mitigate Karstic Risks in Urbanized Areas of Madrid, Spain: A Case Study
}

\author{
Eugenio Sanz Pérez ${ }^{1, *}$ and Cesar Sanz Riaguas ${ }^{2}$ (D) \\ 1 Laboratorio de Geología, Departamento de Ingeniería y Morfología del Terreno, \\ Universidad Politécnica de Madrid, 28040 Madrid, Spain \\ 2 Desarrollos Logísticos y Fomento de Suelo S.L. (DELFOS), C. de Narvaez, 15, 28009 Madrid, Spain; \\ csanz@grupodelfos.net \\ * Correspondence: eugenio.sanz@upm.es
}

Citation: Sanz Pérez, E.; Sanz Riaguas, C. Identification and Investigation of Subsidence Areas to Mitigate Karstic Risks in Urbanized Areas of Madrid, Spain: A Case Study. Sustainability 2021, 13, 7716. https:// doi.org/10.3390/su13147716

Academic Editor: Sotiris Argyroudis

Received: 27 May 2021

Accepted: 7 July 2021

Published: 10 July 2021

Publisher's Note: MDPI stays neutral with regard to jurisdictional claims in published maps and institutional affiliations.

Copyright: (c) 2021 by the authors. Licensee MDPI, Basel, Switzerland. This article is an open access article distributed under the terms and conditions of the Creative Commons Attribution (CC BY) license (https:// creativecommons.org/licenses/by/ $4.0 /)$.

\begin{abstract}
A multidisciplinary investigation was carried out in a karstic depression in a housing development under construction in Madrid to assess its stability. It was found that it is a small basin within a larger depression as a result of subsidence accumulated during the Quaternary. Subsidence has built up progressively in the Miocene clay cap and bedrock due to the underlying dissolution of gypsum rich intercalations. The preferential circulation of the dissolving subsurface flow is along a fault conditioned by subsidence, the formation of an elongated syncline along the fracture, and the alluvial basin. During the Pleistocene, a former lagoon zone was formed in this subsiding area; it was also a groundwater discharge zone. The decrease in recent times is very small and could be evaluated to be about $0.4 \mathrm{~mm} /$ year, and affects the alluvial zone and along the furrow of a fault zone, where the maximum average rate of subsidence would be $1.4 \mathrm{~mm} /$ year. This has led to the development of a relatively strong alluvium. It seems that under the alluvial deposits, a slow and diffuse dissolution is taking place of the shallower clayey gypsiferous levels, free of hypersoluble mineral species; this is somewhat more intense in the fault zone, which is more active hydrodynamically, where groundwater velocity is higher. Microgravimetry surveys indicate that only $5 \%$ of the area hidden under the alluvium shows anomalies, interpreted as residual soft clayey masses, or anomalous alluvial fillings of old dissolution voids. These pockets ("bolsones"), have dimensions of no more than $20 \times 20 \mathrm{~m}$ and depths below $20 \mathrm{~m}$. These measurements have been confirmed by boreholes and are the only points that would require special attention in the future construction of the urbanization. The urbanization work, in full development, is implementing solutions aimed at the stability of the road in the strips of alluvial studied.
\end{abstract}

Keywords: sinkholes; evaporitic karst; karstic subsidence; hazard; risk; microgravimetry survey

\section{Introduction and Objectives}

The nature of karst in evaporite rocks presents a variety of risks associated with construction or civil engineering activities [1]. In the case of the construction of a housing development, the most important factor is the stability of the foundations, referring above all to the existence of possible areas of subsidence and still active karstification. One of the natural risks of karst origin associated with subsidence areas is sinkholes [2,3].

Early identification of subsidence areas is one of the most effective prevention strategies in areas of future urbanization. Hazard assessment involves not only the identification of existing sinkholes, but also their characterization, the prediction of future subsidence phenomena, probabilities of formation, the mechanism of subsidence, expected subsidence rates, etc. These predictions are based on the assumption that future activity will have a similar effect to that of the past. The implementation of these preventive measures requires accurate mapping of the areas affected by subsidence and the delimitation of the 
most dangerous sectors. It is intended to exclude dangerous sectors if they are close to construction sites, in order to avoid significant economic losses.

The delimitation of danger zones with a view to territorial planning is performed, in the first place, by considering the manifestations of active subsidence on the surface. However, consideration must also be given to possible karst phenomena that are occurring in the subsoil but are not yet expressed in the ground, together with those sinkholes active in the past for which there is no evidence at present because they are covered by alluvial formations and anthropic landfills, for example. To this end, it is necessary to develop strategies for the application of appropriate methods for the prospection and "auscultation" of the terrain, which allow the identification of cavities or anomalous landfills as to obtain "early detection" of subsidence. The effective implementation of this "hazard prevention" measure requires the identification and mapping of the edges of existing sinkholes, and the definition of an appropriate setback distance from the edge of the sump [4].

When dynamic processes develop in the ground that are difficult to quantify and predict, conventional geotechnical criteria are not useful, and it becomes necessary to consider and understand geological processes as such. It is no longer an exclusively "technical" problem, it is now a "scientific" problem. A scientific approach is thus required to fully understand a natural phenomenon that involves interconnected processes controlled by the lithology, structure, morphology, hydrology, hydrochemistry, and rheology of the terrain. It is, therefore, a complex phenomenon that must be approached from a multidisciplinary perspective. A specific investigation is required to detect underground cavities and their fillings. This should include geological and geomorphological explorations, geophysical prospecting, and mechanical soundings that allow sufficient detail to be obtained on the anomalies of the subsoil.

In any case, it is essential to plan sufficient geological exploratory drillings and apply appropriate investigation methods. Any reduction in the scope of the investigation will negatively influence the quality of the geological data and inevitably increase the risk. The work in [5-7] is cited as focusing on various aspects related to subsidence phenomena, such as subsidence kinematics and rates, timing of subsidence events, and recurrence. On the other hand, risk cannot be totally eliminated, despite increased research projects, although it can be minimized to an acceptable level. A proper risk reduction strategy is especially important during the design and early construction phases of a development, when there is still space and scope for comprehensive investigations such as the one presented here.

On the other hand, each problem and location has its own characteristics and no case or situation is repeated, so it can be said that in karst areas, especially in evaporitic rocks, not analyzing the problem in detail may result in a certain amount of risk being present for the whole urbanization construction process. In addition, time can be considered as a component of risk, as at some point in time an acceleration of karstification may manifest itself. For example, an eventual lowering of the groundwater table in buildings founded on gypsum with hypersoluble salts can lead to rapid dissolution and the formation of voids. Due to this risk component, monitoring and occasional checks are necessary.

Therefore, the main objective of this study was to identify and study an area of subsidence and reduce karst risks in an area about which little known in this respect, and is beginning to be urbanized in Madrid. The aim is to assess susceptibility in areas where karst phenomena have not manifested recently. The research focuses on several aspects relevant to the assessment of hazards related to subsidence phenomena, such as the origin, mechanisms, and rates of subsidence, as well as the possible presence of hypersoluble salts. The application of different combined methods is also an objective for the achievement of this work. Among these methods, geophysical prospecting stands out. This type of prospecting did not try to cover the entire karst depression (except in the foundation of a viaduct as the most important structure) but rather to know the type and frequency of appearance of these karstified zones and the degree of advance of this karstification. This technique, however, is not conclusive and it was necessary to check by means of surveys. 


\section{Description of the Site and the Problem}

The study area is located in the southeast of Madrid, specifically in the urbanized area of "Los Ahijones", which is located in the Vicálvaro district of Madrid (Figure 1). This urbanized area is 550 ha in size. The influence area of the zone is made up of the old quarter of Vicálvaro, its industrial estate, and other neighborhoods, such as "El Cañaveral" (539 ha), which began construction work at the end of 2006. It is a fairly flat area, where approximately $20 \%$ is urbanized. This district also has a large area of undeveloped land: "Los Berrocales", "Los Ahijones", and "Los Cerros". The urbanization comprises part of the surface area of the hydrological basin of the stream of the same name, which covers a total of almost $7 \mathrm{~km}^{2}$. The area of this study is located at the confluence of the alluvial "Los Ahijones" stream with two natural watercourses, next to the confluence with the "Los Migueles" stream ("del Prado" stream) (Figure 1) and occupies an area of less than one square kilometer.

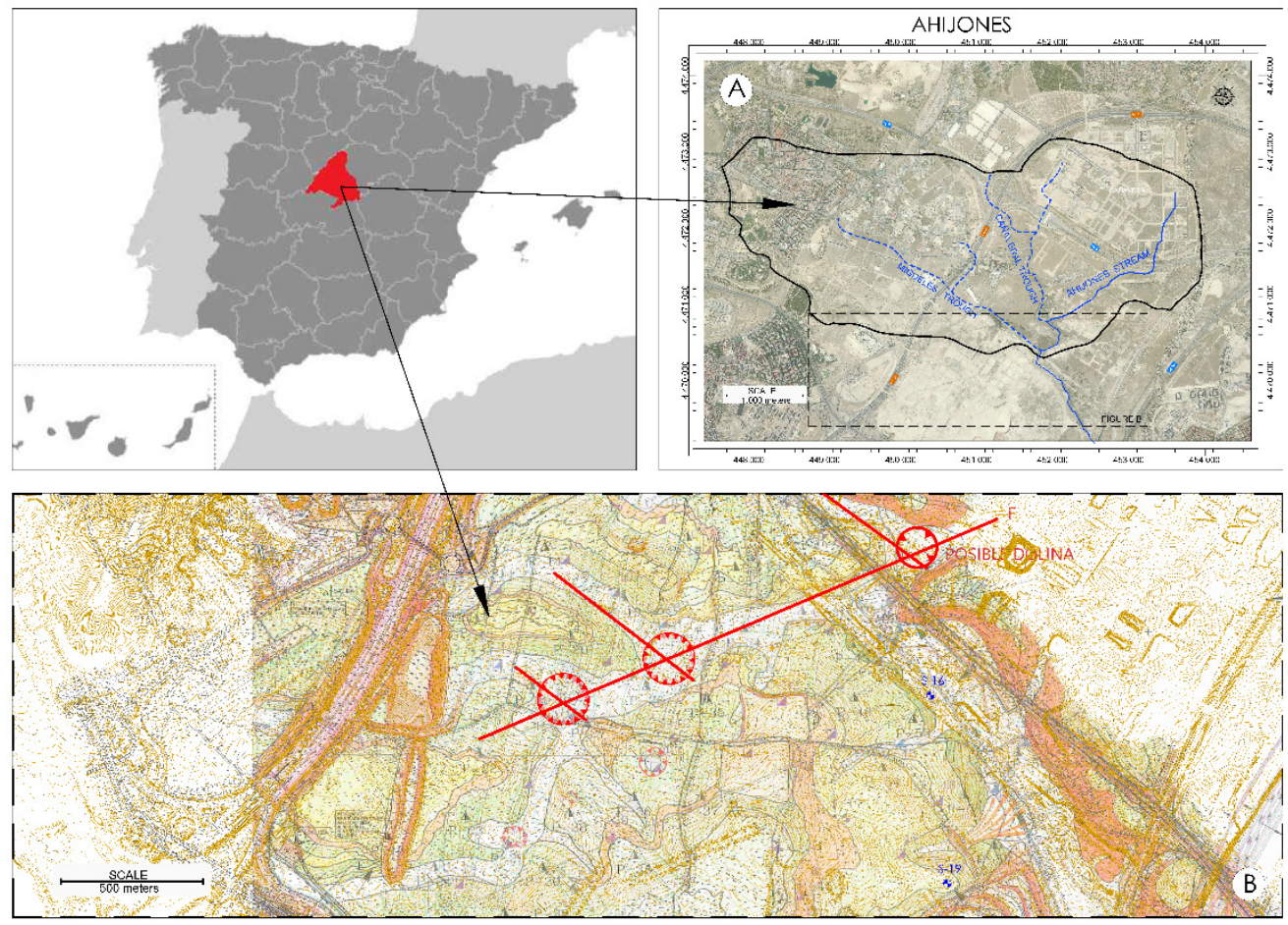

Figure 1. Urbanization of "Los Ahijones" in Vicálvaro (Madrid). (A) The study area: confluence of the "Los Migueles" trough and Ahijones stream; (B) two other soft bottomed sinkholes in alluvial overlying green clays on top of Miocene gypsum and close to the studied doline (the one farthest to the right). The distribution of the sinkholes follows the pattern of being located at the intersection of NW-SE- to SW-NE-oriented drainage networks, which coincide with faults or fractures in the substratum (taken from [8] Reproduction permission).

The most relevant geological and geotechnical aspect in the southeast area of Madrid is the karstification processes that take place in the gypsiferous rocky substratum [8]. In this sense, and as part of previous geological, geotechnical, and hydrogeological work $[9,10]$, a small basin of $500 \times 300 \mathrm{~m}$ was revealed on the southern edge of "Los Ahijones" housing estate, in a sector ("Estevillas" alluvial) that rests on a Miocene clayey and gypsiferous substrate, covered by Pleistocene and Holocene alluvial deposits that are interpreted as the filling of a dissolution depression currently located in a fluvial valley. Project soundings in this area have detected signs of dissolution at the contact of the gypsum layers and the overlying clays, as well as the loss of penetration resistance to considerable depths. The alluvial basin is located in a relatively lower area, which favors the concentration of surface and subsurface flow and thus dissolution, as found in the work of [11]. The development 
site is a large area that is interpreted as a large underlying karstification depression, within which the alluvial basin would be located [12]. On the other hand, it is known that in this area, SE of Madrid, there may be hypersoluble salts at depth, accompanying the gypsum (halite, for example) [1], so the possibility of finding them has also been considered important, since, in the future, and in the event of an eventual alteration of the natural flow, consequent acceleration (or deceleration) of the karstification processes could occur. All this led us to think that this was a subsidence zone where the underlying karstification could still be more or less active.

However, mapping areas affected by subsidence is often a difficult task and can have a high degree of uncertainty. In this particular area, the uncertainty is due to the following reasons:

(1) The identification of sinkholes and subsidence zones in the clayey formations resting on clay-gypsiferous layers of the Miocene of Madrid is not obvious, since, in many cases, they have a subtle and soft geomorphic expression. Moreover, this geomorphological expression is subjugated or erased by sedimentation processes (alluvial, for example) and natural erosion, or filled with anthropic materials. Specifically, in the immediate surroundings, 500-700 $\mathrm{m}$ to the south, there are several sinkholes with a very soft bottom and of a similar size located on green clays ("peñuela") resting on gypsiferous clays or gypsum (Figure 1) [8]. They are located at the intersection of old riverbeds or alluvial channels (which can be interpreted as the intersection of fractures). In other words, the geological situation is exactly the same as the depression we are studying here.

(2) Some depressions are complex and are related to uncertain or mixed origins (e.g., karst, fluvial, and/or lagoonal), although all have a karst origin.

(3) To quantify the current average rate of subsidence, it is necessary to know how long it has been occurring, and we do not always have data to date the most recent geological formations.

(4) There is no evidence of surface manifestations of recent subsidence: looking at the sequence of aerial photographs from 1956 to the present day, there is no evidence of the formation of sinkholes in this particular area. On the ground, there is also no evidence of significant subsidence in the fills that partially cover the alluvium, nor in the embankment of the metro line that borders it.

\section{Methodology}

In this type of study, it is essential to investigate as many surface and subsurface sources of information as possible to provide data on current or past subsidence activity in the study area. Prediction will depend to a large extent on an understanding of the local geology and hydrogeology. A phased sequence of investigation has been used, using, for example, geophysical prospecting prior to drilling boreholes. The methodology followed is explained and justified below:

(1). Compilation and analysis of all previous geotechnical studies of the area and its surroundings. The geological map (Figure 2), in addition to the surveys carried out in this work, also shows the situation of the surveys carried out prior to the aforementioned reports.

(2). Detailed topographic survey of the basin with equidistance of $0.25 \mathrm{~m}$ in order to identify closed depressions.

(3). Detailed geological mapping of the subsidence depression including slopes and surroundings of the alluvial sector studied, at a scale of 1/2000 (Figures 2 and 3). The aim was to assess the geology under the alluvium by the extrapolation of outcrops, especially the layer of massive gypsum and its degree of karstification. As the geology beneath the alluvium could not be easily measured using the dimensioned representation system, other techniques were used to draw inferences about it. Due to the thickness of the alluvium, the trial pits did not seem to reach the substratum easily. Due also to the presence of a flint bolus in the same alluvium, which could lead to rejection, penetrometers were also rejected. Therefore, a geophysical campaign was planned to identify cavities or anomalous fills and to obtain "early detection" of subsidence. 


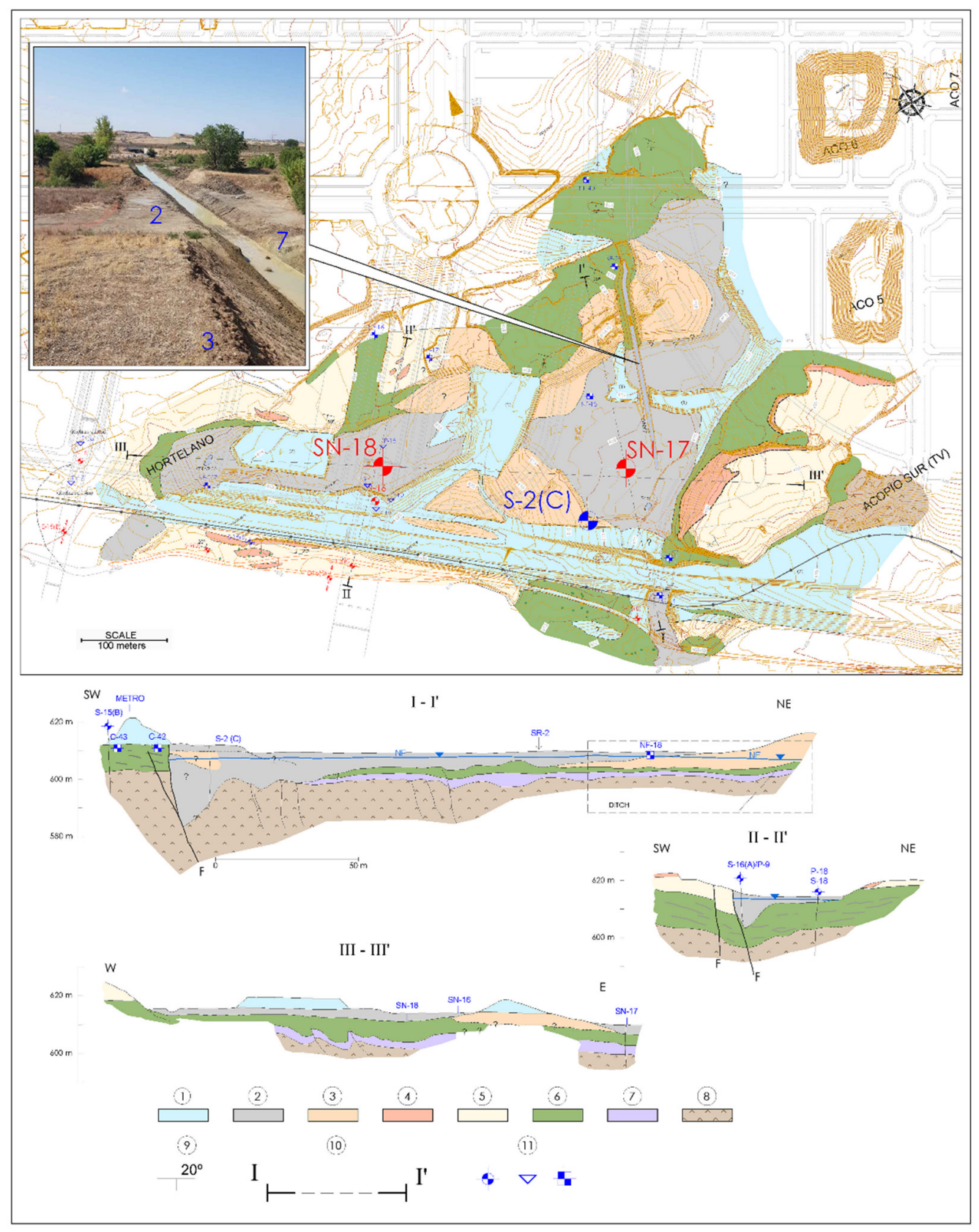

Figure 2. Geological map of the subsidence basin. (1) Anthropic landfill (Quaternary). (2) Alluvial (Holocene). (3) Terrace (Pleistocene). (4) Calcareous tuffs (Miocene). (5) Sands, chert nodules, and dolomites. (6) Green clays and silts ("peñuela"). (7) Clays and green silts with gypsum intersperses. (8) Massive gypsum. (9) Direction and dip. (10) Geological cross sections. (11) Surveys: boreholes, penetrometers, test pits, trenching. The photo shows the northern edge of the subsidence basin with the geological contact in the trench between the green rock (7) and the Holocene alluvial overburden (2). In the foreground, sandy deposits corresponding to terrace level T4 (3), which is overhanging in this sector. 


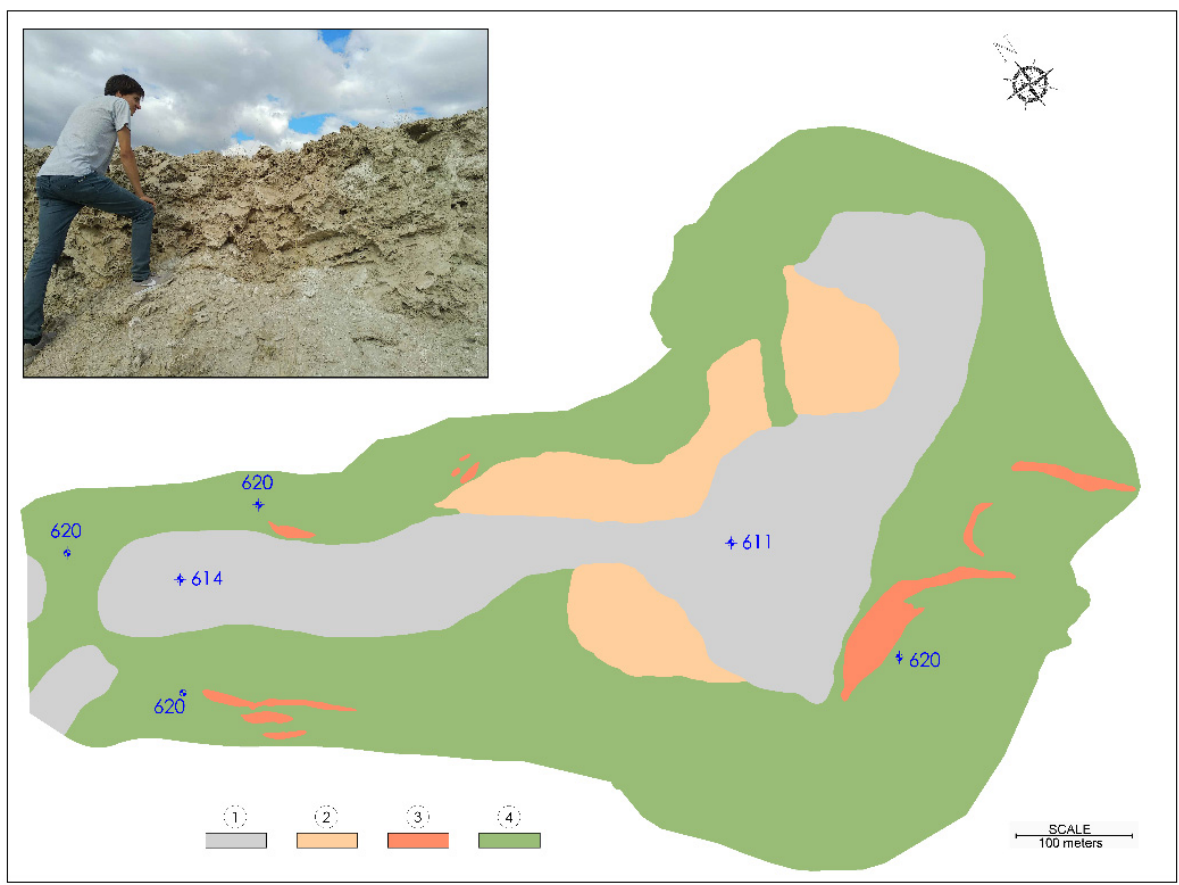

Figure 3. Geological scheme of the alluvial of "Los Ahijones" and "Estevillas" streams, showing the remains of tuff outcrops. The photo shows the calcareous tuffs with casts of ancient gypsum crystals.

(4). Geophysical prospecting. The geophysics strategy followed was determined by the result of the dissolution processes to be detected. According to local experience [9], the result of these processes can be divided into three types of cases: (1) actual hollow spaces; (2) strong fillings of quaternary sediments in the form of the pockets of old hollows in the gypsum of the substratum; and (3) poorly consolidated silty clayey fillings of low density that are the residue left over from an area of an original layer of gypsiferous clays where the gypsum has been dissolved.

The strategy consisted of carrying out a preliminary study by means of refraction seismic and electrical tomography with four profiles along the length and width of the two sectors in which this alluvial could be subdivided in order to identify the substratum layers and Quaternary thicknesses (Figure 4). In the case of tomography, it was also aimed at distinguishing "anomalous" areas such as possible clay rich or debris rich fills [12]. The presence of a conductive wet clay substrate below the water table discouraged the use of ground penetrating radar (GPR) [13,14], which has been so useful in detecting the voids and fills of former flint workings in this urbanization.

Refraction seismic measurements were made using a 24-channel digital seismograph, model Summit II Compact (s/n 10070027), together with vertical geophones, type SM-4U, with a natural frequency of $10 \mathrm{~Hz}$. The seismic deployments were $115 \mathrm{~m}$, made up of 24 geophones spaced at $5 \mathrm{~m}$ intervals. Signal recordings were produced at seven shot points per deployment, with one shot point every four geophones. This study operated with an overlap of six geophones between adjacent deployments.

A Super Sting R8 system (s/n 0609219) with a connection box for the simultaneous control of up to 112 electrodes distributed in 8 special cables of 14 electrodes per cable was used to measure the apparent resistivity of the ground. Electrical tomography measurements were performed using a pole-dipole type focused device with the appropriate characteristics to achieve the required research depth, with the highest possible lateral and vertical resolution. These characteristics were as follows: Electrode spacing, $a=5 \mathrm{~m}$. Number of depth levels measured, $\mathrm{n}=16$. 

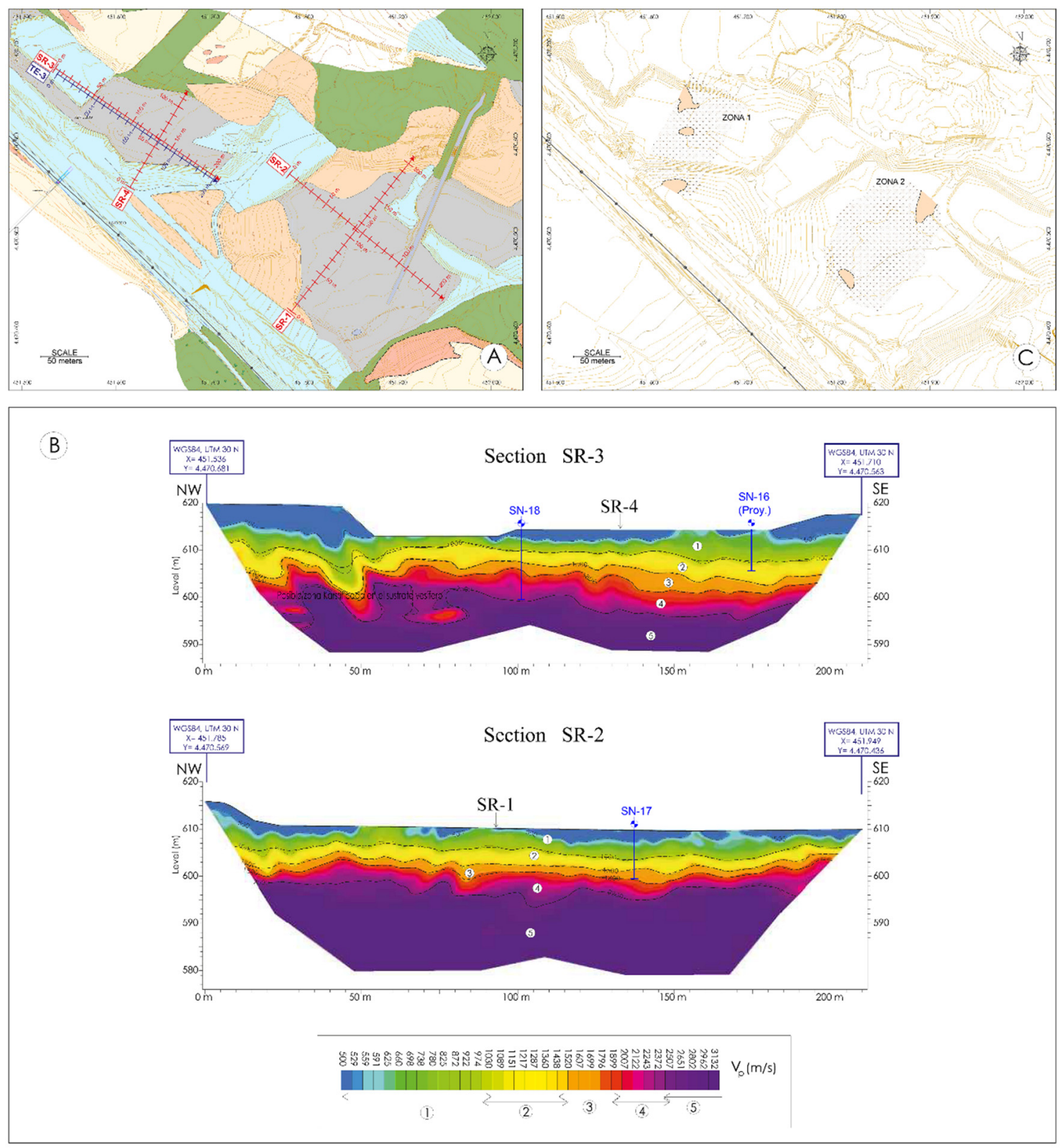

Figure 4. Geophysical surveys. (A) Location of the four refraction, seismic, and electrical tomography profiles in the alluvial basin. (B) Above: refraction seismic profile SR-3, showing on the NW side a series of "folds", probably corresponding to faults tilted towards the SE and the development of "karstifications" and soft clayey masses. Below: seismic refraction profile SR-2 showing a zone of altered gypsum (4). (1) Quaternary alluvial and anthropic landfills. (2) Green clays and silts ("peñuela"). Sands and dolomites. (3) Clays and green silts with gypsum intersperses. (4) Altered and karstified gypsum (5) Massive gypsum. (C) Location of the most relevant gravity minima in the two surveyed areas.

Finally, it should be noted that geophysical measurements were carried out on all profiles without any interference, obtaining good quality data.

On these last geophysical surveys, another method of higher resolution was applied, microgravimetry. A high resolution microgravimetry survey was carried out with a dense network of measurement points (with an accuracy of 5-6 $\mu$ Gales). In the area in question, microgravimetry can be considered, in principle, as a method that could provide a satisfactory explanation for the presence of the three cases of dissolution mentioned above. The morphological traces left by the dissolution processes show a relative loss of mass and consequently a reduction in gravitational attraction [15]. The measured variations are interpreted in relation to the existence of the three possible cases cited in the subsoil at a 
survey depth of no more than $25 \mathrm{~m}$ and present a strong contrast in density with respect to the surrounding medium.

IGT used an Autograv CG-5 microgravimeter to carry out this study. To determine the absolute elevations of all the measurement points of this study and existing significant topographic projections, a Leica TCRP-103 total station with an angular accuracy of $6 \mathrm{~s}$ and a GPS Hiper Pro-GPS system were used.

This survey was subdivided into two sectors of half a hectare each. As has been said, the aim was not to cover the entire depression (except for the foundations of the viaduct of the most important structure, Figure 4), but rather to determine the type and frequency of occurrence of these "karstified" areas, and the degree of progress of this karstification according to the differentiation of the cases mentioned. The map in Figure 4 shows the location of the refraction geophysics lines, electrical tomography, and areas investigated with microgravimetry.

(5). The drilling of two research boreholes in the geophysical anomalies was detected in the two aforementioned alluvial sectors (SN-17 and SN-18) (Figure 4). It should not be forgotten that different phenomena in the subsoil can lead to a similar response. The characteristics of the anomalies must be confirmed by intrusive methods such as probing, drilling, or trenching [16].

These probes reached the gypsum and allowed for the recognition of sediments disturbed by karstification processes. In addition, detailed test drilling has been carried out, accompanied by $\mathrm{X}$-ray diffraction analysis to identify the possible presence of hypersoluble minerals. These analyses are essential as it is very difficult to identify visually mineral species such as halite, thenardite, epsomite, etc., when they are dispersed. Water analyses were also carried out as the boreholes were included as piezometers in a wider piezometric observation network that includes the entire urbanization.

(6). Retrodeformation analysis. On the other hand, the documentation of 35 boreholes and 90 research trial pits distributed throughout the development from previous works $[9,10]$ made it possible to reconstruct the geological structure of the site in great detail: synclines, fault planes, collapse zones, etc., and gave information on the mechanisms and cumulative displacement on subsidence. This has allowed for the analysis of retrodeformation through the progressive restoration of the sedimentary layers and the interpretation of subsidence episodes over time, as well as finding out the somewhat uncertain origin of the "Los Ahijones" depression.

(7). Direct inspection of road excavation, earthworks, and trenches. The numerous and extensive excavation works in most of the development have allowed for direct inspections that have provided additional objective information on the characteristics and chronology of the deformation history, incorporating a temporal dimension that is generally lacking in other research methods. Paleokarst and other ancient karst subsidence zones, for example, have been recognized.

(8). Determination of the age of the surface formations according to the bibliography and eventual geochronological dating in some tuffs surrounding the depression, in order to quantify subsidence rates according to quaternary thicknesses and measured deformations.

(9). Hydrogeological investigations. Understanding the hydrogeology (including hydrogeochemistry) of a study area is a crucial aspect of subsidence hazard analysis. Groundwater flow is the geological agent responsible for karstification in evaporite rocks and is often one of the most important conditioning and triggering factors of the generation of sinkholes. We also carried out the hydrogeological study of the area, including flow modelling [10]. The results of this study will be used for the purposes of this work.

(10). Prospecting to detect the possible presence of hypersoluble salts. In the Miocene subsoil of southern Madrid, the typical facies of evaporites can be arranged from roof to wall as follows: gypsum $\left(\mathrm{CaSO}_{4} \cdot 2 \mathrm{H}_{2} \mathrm{O}\right)$, unaltered thenardite $\left(\mathrm{Na}_{2} \mathrm{SO}_{4} \cdot 7 \mathrm{H}_{2} \mathrm{O}\right)$ / glauberite $\mathrm{Na}_{2} \mathrm{Ca}\left(\mathrm{SO}_{4}\right)_{2}$, halite $(\mathrm{NaCl})$, glauberite, and halite, with thenardite and halites being very soluble. Sometimes they are accompanied by other very soluble minerals, such as mirabilite (Cienpozuelita) $\mathrm{Na}_{2} \mathrm{SO}_{4} \cdot 10 \mathrm{H}_{2} \mathrm{O}$, Polyhalite $\mathrm{K}_{2} \mathrm{Ca}_{2} \mathrm{Mg}\left(\mathrm{SO}_{4}\right)_{4} \cdot 2 \mathrm{H}_{2} \mathrm{O}$ and epsomite 
(Vaciamadrid salt) $\mathrm{Mg}\left(\mathrm{SO}_{4} \cdot 7 \mathrm{H}_{2} \mathrm{O}\right.$. The presence of these salts may play an important role in the development of dissolution induced subsidence in these doline zones, or may pose the risk of the rapid acceleration of karstification if water conditions are altered, such as in tunnels [16].

In order to detect the presence or absence of hypersoluble minerals, the following tests were carried out:

i. $\quad$ Two research boreholes (SN-17 and SN-18) were drilled to a depth of approximately 595-597 m. Research was carried out to detect special salts up to this level, although it is assumed that the results are also valid for somewhat greater depths. However, as it is sometimes difficult to recognize such salts visually if they are present in small quantities, they were identified indirectly by water analysis and directly by mineralogical analysis.

ii. Chemical analysis of groundwater from the gypsum beneath the alluvium, which was obtained from piezometers SN-17 and SN-18.

iii. Analysis of water from the dissolution of salts present in cores (chosen from the depth where the most gypsum appears) from boreholes SN-17 and SN-18 (by immersing the cores in distilled water for $60 \mathrm{~h}$ ).

iv. Semiquantitative analysis of samples by X-ray diffraction, and study of thin films for petrographic microscopy.

\section{Results}

\subsection{A Small Closed Topographic Depression in the Alluvial Trough}

As a result of a detailed topographic survey, a rounded topographic depression of about $80 \mathrm{~m}$ in diameter and no more than $0.5 \mathrm{~m}$ of negative curves appeared in the southeast area of the basin. It can be interpreted as a very soft doline that tends to become waterlogged when it rains.

\subsection{Stratigraphy of the Subsidence Alluvial Basin}

The stratigraphy described in detail here refers to the small subsidence basin under study, although the stratigraphy of the Miocene substratum of the rest of "Los Ahijones" depression is also reported. In the geological map in Figure 2, we can differentiate the following geological units, ordered from oldest to most modern:

Miocene geological formations:

- More or less massive lower Miocene-Middle Miocene lower unit. It has been cut into several boreholes in previous projects and in those carried out for this study near the bottom of the alluvial.

- Clays with intercalated layers of gypsum or gypsum with intercalated layers of clay. They also do not outcrop, but have been identified under the alluvial in the previous boreholes and in the two research boreholes mentioned above. In the refraction seismic profiles, they are identified with velocities of between 1500 and $2000 \mathrm{~m} / \mathrm{s}$, and powers between 0 and $7 \mathrm{~m}$.

- As an integral part of this unit, dark green clays appear in areas that are poorly differentiated from the rest and are interpreted as the residue of the karstification of the gypsum rich layers.

- $\quad$ Clay and green silt laminated with intercalated layers of fine to medium grained, very micaceous sands ("Peñuela" in the area). According to soundings, the thickness varies between 5 and almost $10 \mathrm{~m}$.

- $\quad$ Sandstones, dolomites, limestones, flint levels, and clay intercalations. This is the most permeable "layer" within the intermediate unit and here it has a small thickness, no more than $3 \mathrm{~m}$; under the alluvial it hardly appears at all.

- $\quad$ Sepiolite clays. They outcrop outside the area, to the east. They do not occur under the alluvial.

Quaternary surface formations

We distinguish, from older to more modern: 
- Limestone calcareous tuff. Remnants are preserved on the edges of this depression, between 10 and $11 \mathrm{~m}$ above the bottom of the depression, in the form of hanging terraces towards 620-622 m, except on the southeastern edge, where they are scattered and broken all along the slope up to $612 \mathrm{~m}$, probably indicating a resubmergence towards the interior of the depression. These tuffs are associated with the more permeable Miocene sandstone levels. These are masses of calcareous tuff with many hollows in the form of smooth walls, which have probably harbored gypsum crystals that have subsequently dissolved (Figure 3). To assess the rate of subsidence, it is interesting to know the age of the tuffs. An attempt was made to date this tuff by means of U/Th, but this was not possible as the terrigenous content was higher than $15 \%$. According to the geomorphological maps of [11], these tuffs seem to be synchronous with those of the T2 terraces (PC-4), also located at an elevation of $622 \mathrm{~m}$ and dating from the Middle Pleistocene, and have been dated to 115,000 years ago. This is confirmed by the fact that within the tuffs there are remains of worked flint from the Mousterian.

- Terrace R4. Thanks to the excavation of a trench in a N-S direction, and slightly more than $200 \mathrm{~m}$ long with a depth varying between 8 and $1.5 \mathrm{~m}$, the northern edge of the basin has been revealed. The schematic geological section along the trench is shown in Figure 2. From north to south there is a first section excavated in "peñuelas clays", on which are supported, in the area closest to the depression and for a length of $35 \mathrm{~m}$, the deposits of hanging terrace T2, which [11] reveals indicates an age of 115,000 BP, corresponding to the Middle Pleistocene. It is a 4-m thick detrital deposit formed by two poorly defined layers: the lower one is of coarse sand with flint at the base. It is separated from an upper one formed of fine sands by a flint layer up to $40 \mathrm{~cm}$ in size. In the upper part there is another level of flint. These levels are inclined towards the center of the depression by $10-15^{\circ}$. Right at the base of these deposits, the "peñuela" is seen to sink and is covered by Holocene muddy sediments and organic matter at least $0.5 \mathrm{~m}$ thick, where the water table emerges (Figure 2, geological cross section I-I' and photography). These sediments also occur on the southern edge of the fault where they dip below the Holocene, as imbricate terraces.

- Holocene Alluvial Deposits

Initially, it was thought that the T4 terraces were imbricated with respect to the Holocene alluvial deposits, as is partially the case in other alluvial paleochannels of "Los Ahijones", according to [11]. The results of these surveys, the cuts of the drainage trench, and the research drillings do not seem to confirm this imbrication in all the edges of the basin: the T4 terraces are hanging in a sector of the northern edge (in the ditch zone, as already mentioned), but in the fault zone and axial zone of the syncline there is possibly punctual imbrication. The Holocene has an overall thickness of less than $4 \mathrm{~m}$ and consists of dark brown clayey muds and soils with organic matter in the upper part, and feldspar and quartz sands and some gravel in the rest. However, in the southern edge fault zone, there are average thicknesses of more than $10 \mathrm{~m}$ that are considered Holocene.

\subsection{Structure of the Great Ahijones Depression and the Subsidence Trough}

Using data from the numerous boreholes and test pits available, isoline maps of the absolute elevation and depth of the contacts of the substratum layers defined above have been generated. With these maps, it has been possible to make a geological cross section representative of the urbanization. We can see in this geological section that the layers are subhorizontal, although they adapt to a dissolution depression that affects the gypsum, giving rise to a syncline and a fault. The great depression of "Los Ahijones", some 500 ha in size, forms a depocenter, where, due to the underlying karstification processes concentrated in a NW-SE fault coinciding with the Migueles stream, an elongated and narrow syncline has been created in the clayey cover, which has had an important influence on underground drainage [10]. 
This fault is in line with the bed of the "Los Migueles" stream and, although it was not known, it must be included in the group of faults that affect the substratum in this part of the Tagus basin and are also reflected in the cover. This fault is of the direct or normal type, measuring a drop of about 5-10 m, with the sunken block being the one to the north. This local resubmergence has preserved the entire stratigraphic column from erosion, including the Quaternary.

Referring to the alluvial basin, and as can be seen in the map and geological sections of Figure 2, the dips in the outcrops of the Miocene substratum of the alluvial environment are all directed towards the center of the depression with values between $8^{\circ}$ and $20^{\circ}$, the latter near the fault zone of the southern edge. As mentioned above, the Pleistocene T4 terrace deposits and tuffs also dip up to $15^{\circ}$ towards the center of the depression. The geological cross sections in Figure 2 show how, near the fault zone, the Miocene subsidence has been greater, forming the bottom of a syncline and the greatest thickness of the recent Quaternary.

\subsection{Characteristics of Paleokarst}

Within the large "Los Ahijones" depression, sedimentation during the Quaternary has been controlled by subsidence, caused by more or less localized karst processes. A network of Pleistocene paleochannels is highlighted, adjusted to fractures where sedimentation is strongly controlled by the underlying karstic subsidence, causing locally significant sedimentation rates, and even lacustrine deposits. These paleochannels, around which the geoarchaeological sites are located, are arranged parallel to the present day channels of the depression. In the present day valley floor channels, it is common to see the presence of Pleistocene deposits stratigraphically below the Holocene deposits [11]. There are also two subsidence sinkholes filled with Pleistocene sediments no more than $4 \mathrm{~m}$ thick and measuring $100 \times 200 \mathrm{~m}$ [11]. In the land clearance of the nearby M45 highway, synclines of up to $300 \mathrm{~m}$ can be recognized, with residual dark green clays at their base, which are the result of the dissolution of the gypsum. These dark green clays can also be found around the alluvial basin.

\subsection{Existence of Karstification in the Gypsums}

It has already been said that boreholes around the fault zone of "Virgen de la Torre" hermitage corresponding to the previous geotechnical projects showed numerous symptoms of karstification in the gypsum, such as the existence of residual dark green clays from layers where the gypsum has been dissolved, intercalated, or mixed, small hollows, or areas where the resistance to penetration has been very low.

The different levels that we have differentiated in the seismic sections and the Vp values that characterize them are the following: Anthropic fills ( $\mathrm{Vp}<500 \mathrm{~m} / \mathrm{s})$, Alluvial (500 m/s < Vp $<1000 \mathrm{~m} / \mathrm{s})$, clays ("Peñuela") without casts $(1000 \mathrm{~m} / \mathrm{s}<\mathrm{Vp}<1500 \mathrm{~m} / \mathrm{s})$, clays with casts $(1500 \mathrm{~m} / \mathrm{s}<\mathrm{Vp}<1800 \mathrm{~m} / \mathrm{s})$, casts $(1800 \mathrm{~m} / \mathrm{s}<\mathrm{Vp})$. Within the gypsums, we have differentiated between weathered and healthy ones, placing the limit between the two at around $\mathrm{Vp}=2500 \mathrm{~m} / \mathrm{s}$.

One of the refraction seismic and tomography profiles seemed to indicate possible anomalous karstified zones on top of the massive gypsum as possible clay rich fillings (Figure 4). Due to this uncertainty, microgravimetry tests were completed.

The microgravimetry survey identified five small amplitude gravity minima (Figure 4), two of which were anthropic fills. The other three should be associated with the three possible cases mentioned above, or a combination of these. In an anomaly, a borehole (SN-18) was drilled, which allowed us to recognize that it was a soft clayey gypsiferous zone from the Miocene up to $16 \mathrm{~m}$. This is probably the same as with the other anomaly B1, where there is little alluvium thickness. Other anomaly data from another borehole (S-2 in Figure 2) were also available, which confirmed the thickening of the alluvium on this side close to the $14 \mathrm{~m}$ fault zone. 


\subsection{Hydrogeology}

The piezometric control network shows that the water table is well adjusted to the topography, with a fairly epidermal flow associated with the clayey formations of the Miocene. The role played by the elongated and faulted syncline of a NW-SE direction and higher permeability, which conditions and redirects the regional flow to a great extent, is highlighted (Figure 5). The hydrogeochemical conceptual model is well explained by the geology of the site: the predominance of calcium-magnesium bicarbonate facies in the Miocene clayey layers, and calcium sulphate facies when there is the influence of the gypsum if they are close, either at depth or in the areas located to the east where they outcrop.

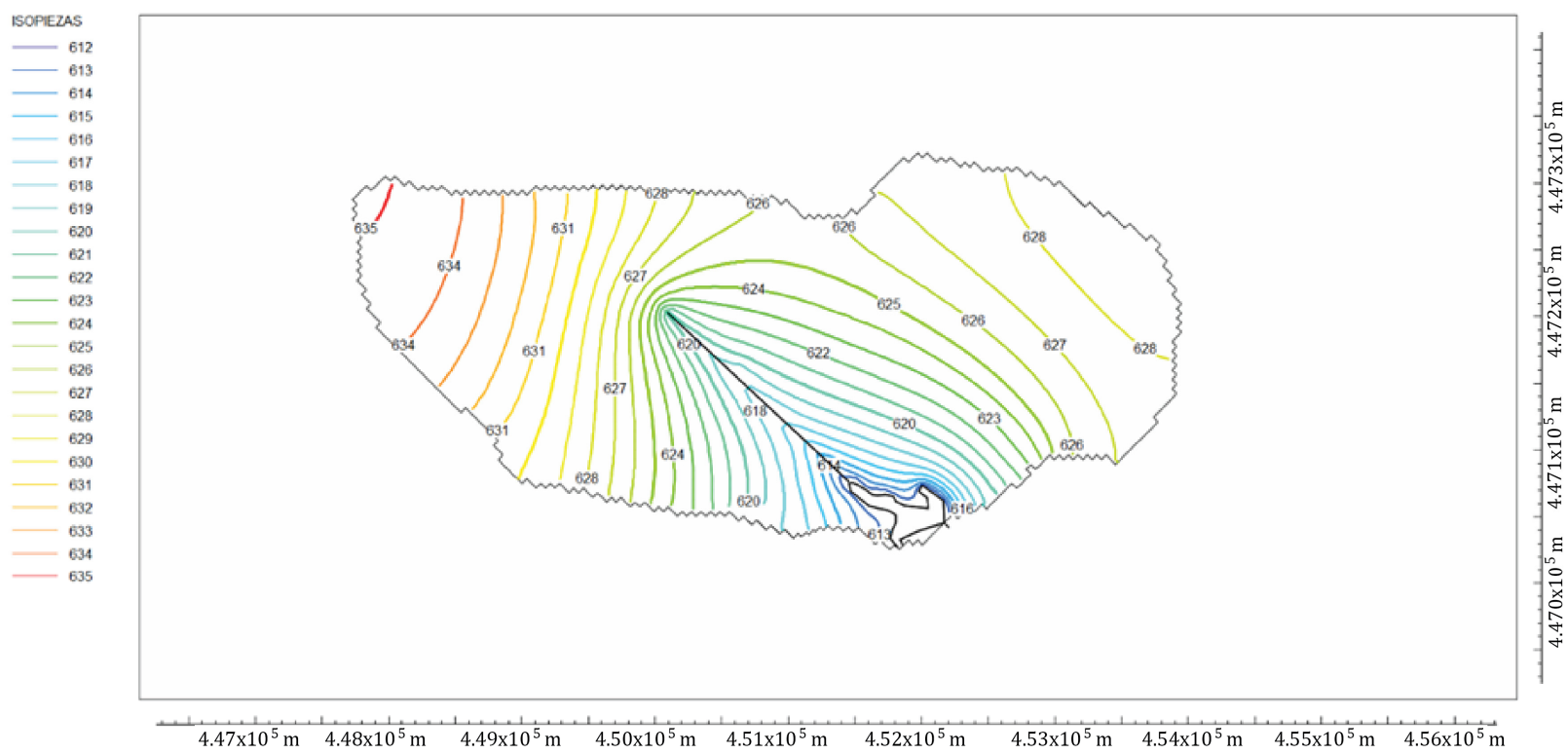

Figure 5. Simulated groundwater contour maps in the "Los Ahijones" development. Note how the flow is directed towards the syncline fault axis (black line) and alluvial subsidence basin (according to [10]. Reproduction permission).

With regard to the application of MODFLOW, two simulations were carried out: one in the natural regime prior to the works, where the isopiestic line map was used based on the level of the wells and test pits carried out in the 2006 geotechnical project, and another in 2019, in which a piezometric network of numerous boreholes drilled specifically for this purpose was available. There was also a large amount of permeability data (Lefranc tests) and a very precise geometry of the different hydrostratigraphic units, so that transmissivity estimates were fairly accurate. Natural isotopes showed that the origin of the recharge was rainfall and was preliminarily quantified by means of hydraulic balances $(9,10)$. This was used to simulate various current situations, such as the effect of a long network of drainage ditches on the groundwater table, or the decrease in recharge due to the partial urbanization of the area from 2019 onwards.

Modelling of the aquifer [10] has revealed that natural recharge in the clay aquiclude is minuscule and does not reach $1 \%$ of the useful water of the hydraulic balance $(0.16 \mathrm{~mm} /$ year $)$. It has also revealed the general hydrogeological behavior of the lower gypsum layer. This layer has a general permeability similar to that of the clay aquiclude (despite possible local karstification) and is recharged in an induced manner through this layer. It discharges into the lower part of the alluvial part of "Los Ahijones" stream via an upward flow and longer streamlines, which explains the high sulphate content of the groundwater in this area. This flow has been quantified by MODFLOW simulation to be no more than $2 \mathrm{~L} / \mathrm{s}$ [10]. 


\subsection{Presence of Water-Soluble Salts?}

In the visual inspection of the evaporite samples obtained from the two boreholes mentioned above, only gypsum was recognized, and no hypersoluble salts were clearly identified. On the other hand, and according to the chemical analysis of the piezometer samples, the groundwater is dominated by calcium in the gypsum, but the ionic content of chlorides and sodium is small, so the water has a sulphate facies, typical of gypsum, but does not present significant amounts of chlorides or $\mathrm{Na}$, which would have indicated the presence of halite, thenardite, or glauberite, for example.

The water analyses from the dissolution of the salts present in cores (chosen from the depth where the most gypsum appears) from each of boreholes SN-17 and SN-18 have a certain proportionality with the groundwater analyses, but give lower values, as expected. Nor are there significant amounts of chlorides and sodium, indicative of the significant presence of hypersoluble salts.

In addition, semiquantitative analyses of samples by $\mathrm{X}$-ray diffraction and thin sheet petrographic microscopy have not detected significant contents of highly soluble mineral species beneath the quaternary alluvium. There is no halite, polyhalite, or epsomite, which could be suspected to be because of the high $\mathrm{Mg}$ content in the water; for example, it is seen that the high content of this ion is due to the magnesian clays in the "peñuelas".

\section{Discussion}

\subsection{History and Characteristics of Subsidence}

The technique for the investigation of subsidence zones in evaporites focuses on several aspects related to subsidence phenomena relevant for risk assessment, such as subsidence mechanisms and kinematics, subsidence rates, timing of subsidence events, and recurrence [17-19].

With reference to our study area, the large depression in the "Los Ahijones" clayey cover has been formed by the progressive dissolution of the interstratifications of gypsum between the underlying clays and the lower gypsum, a process that probably began in the Miocene. The underlying and internal karstification operated throughout the Quaternary by the concentration of groundwater flows along a NW-SE fault, which caused the resubduction and passive bending of a Miocene gypsiferous and argillaceous bedrock and bedrock of ductile rheology, with the formation of an elongated and narrow atectonic syncline along the fault (Figure 6). These depressions by the gradual flexure of the overlying mantle are usually shallow depressions and can reach several hundred meters in length, although there are other cases of several kilometers described in [20]. On the other hand, the "karst residue" near the contact zone between the overlying mantle rock and the nonkarstified gypsiferous rock is a characteristic dark green clay. The internal processes of karstification and deformation are controlled by different factors [14,21-23], including, among others, and in our study area, the small laminar subsurface flow of sulphate undersaturated waters that circulate through the clays [10] but are effective when acting over geological time. The absence or scarcity of highly soluble mineral species in these upper parts of the clay gypsiferous facies has contributed to lower subsidence rates and to the fact that subsidence has manifested itself predominantly by bending rather than collapse. 

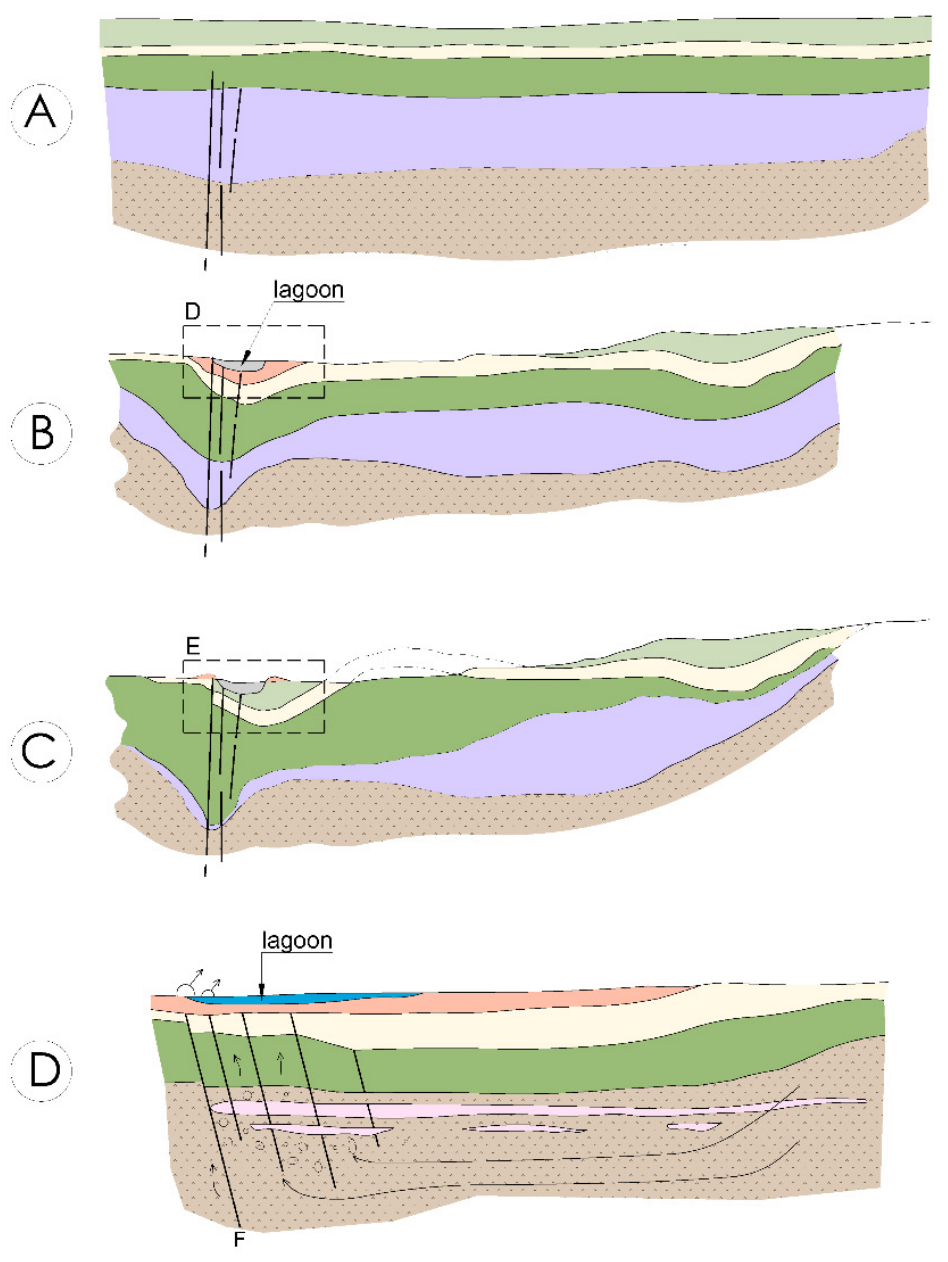

E
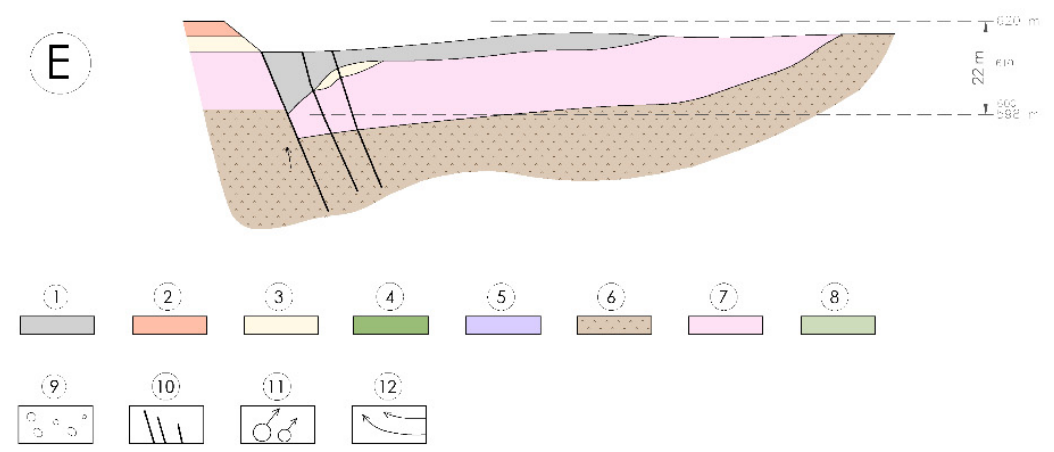

Figure 6. Retrodeformation analysis to the investigation of subsidence evolution in Ahijones karst. (A) Undeformed deposits in the Miocene. (B) Gradual subsidence and synsedimentary gradual subsidence in the Quaternary. Along the Pleistocene, where the depression caused by preferential dissolution in the gypsum in the discharge zone of the subsurface flow created a lagoon with tuffs on the shores (Detail in (D)). This deformed the Miocene clay cover subsided into a syncline (C). The process continues today, with the overaccumulation of anomalous thicknesses in the fault zone (Detail in (E). $22 \mathrm{~m}$ is the cumulative displacement). (1) Holocene alluvial. (2) Calcareous tuffs. (3) Miocene sandstones (aquifer). (4) Miocene green clays ("peñuelas"). (5) Clays and green silts with gypsum intersperses. (6) Massive gypsum. (7) Residual clays of (4). (8) Clays and sepiolites. (9) Cavities due to karstification. (10) Fault zone. (11) Springs in lagoon. (12) Groundwater flow lines.

During the Pleistocene, and in the most subsided fault zone, a semilagoonal environment developed in a groundwater upwelling zone that drained the more permeable 
Miocene sandstone levels, and with the precipitation of calcareous gypsiferous tuffs on the banks. The sandstones must have formed an aquifer, as they do today, and had their outlet in this lower zone. These are undoubtedly deposits associated with areas of fresh but fouling water upwelling that accumulated on the edges of a lagoon where there was also sulphate precipitation. Evaporation aided this. This is a unique example of palaeogeographical and palaeohydrological significance in this area of Madrid. The lagoon was not only supplied underground but also by a stream, "Los Ahijones" and two natural tributary channels (paleochannels) that filled it with sediment. These tuffaceous outcrops form the perimeter of a lagoon with a surface area of about $21 \mathrm{ha}$, which is the alluvial basin that is still preserved today (Figure 3).

Subsequently, this fault continued to condition the evolution of the karstic subsidence and, consequently, the interaction with the previous sedimentological processes, such as the fact that on the north side of the microwell the Pleistocene terraces are hanging, although inclined inwards by $15^{\circ}$, and that, on the edge of the fault, the major subsidence has conditioned the local imbrication of these terraces. In the fault zone and axial zone of the synclinal fold, a collapse occurred that sank a section of approximately half a kilometer in length, from the Virgen de la Torre hermitage to the junction of the three streams. This fault collapse indicates that subsidence has not always been progressive and constant. The collapse is demonstrated by: (a) Abnormally large thickening of the alluvium, with thicknesses of between 9 and $11 \mathrm{~m}$. It is a fill that fits into the narrow depression generated in this active zone of the fluvial system along the fault and into which the fluvial network fits. (b) The tuffs on the southeastern edge of the trough above the fault zone are fractured and reach up to $612 \mathrm{~m}$; they indicate a fault jump of about $10 \mathrm{~m}$ and a resubsidence into the depression.

In other areas of the great depression of Los Ahijones, there are two isolated ancient sinkholes filled with Pleistocene sediments [11] with no karstic activity in the Holocene or at present. The same is true of the paleochannels, where the Holocene is not very strong. The paleokarst shows the mechanisms by which subsidence progressed in the past and was later aborted by the preference of the subterranean flows to head towards the main fault and an associated alluvial basin of lower elevation. We see that, on a large scale, and as mentioned above, this subsidence has been slow and progressive throughout Los Ahijones. However, more selectively, subsidence has operated in a linear fashion through channels adjusted to major fractures (paleochannels). From the beginning, we have highlighted the fault of the Virgen de la Torre hermitage, which acquired greater hydrogeological relevance over time.

Although this lagoon depression was later captured by the valley of "Los Prados" outfall river, a tributary of the Manzanares River, it remained a residual quasi-enclosed area, with a more sunken part at the junction of the three tributary streams, which must be interpreted as the intersection zone of three fractures.

The edges of the basin have been stable since at least the Middle Ages, as attested by the "Ermita de la Virgen de la Torre" and the medieval settlement of "La Torre" (although it was also inhabited in the early Roman period) [24], both of which are located right on the western edge of the basin.

At present, the eastern area is a sinkhole prone to waterlogging, with a bottom below the water table and a Holocene muddy fill rich in organic matter. It is an area of groundwater discharge, although the flow is very small. In this dissolution induced alluvial basin, the water that rises on the western edge is of calcium-magnesium bicarbonate facies and has flowed through the clayey and sandstone Miocene. The water that rises in the eastern doline is of sulphate facies, revealing the nearby presence of gypsum, but without ions characteristic of hypersoluble salts.

\subsection{Subsidence Rates}

The average underlying karstification subsidence rate of this basin was deduced in the past from the altimetric and chronological position of the reference level of the tuffs and, 
more recently, from the thickness of the alluvial fill. From the age of the tuffs $(115,000 \mathrm{BP})$ to the present, there has been a subsidence of $22 \mathrm{~m}$-from the initial level of $620 \mathrm{~m}$ (level of the tuffs) to $598 \mathrm{~m}$ (bottom of the alluvium) $=22 \mathrm{~m}$ (Figure 6E) - from which an average subsidence rate of $0.19 \mathrm{~mm} /$ year can be deduced. If we consider recent times, in the Holocene (10,000 years ago), and taking an average alluvial thickness of $4 \mathrm{~m}$ according to the geophysical survey, the average subsidence rate would be $0.4 \mathrm{~mm} /$ year. At a specific point, and close to the fault zone furrow, the greatest recognized thickness was $14 \mathrm{~m}$ (in the S-2, according to [9]); if we assume that everything is Holocene, this would result in a maximum average subsidence rate of $1.4 \mathrm{~mm} /$ year.

The resulting subsidence values are very low and not comparable with active doline areas such as those in the gypsiferous environment of Zaragoza, for example, which are well documented. The average subsidence rate in paleo sinkholes in Zaragoza (Spain) was -2$9.2 \mathrm{~mm} /$ year, and $-24-92 \mathrm{~mm} /$ year in present day sinkholes [25]. Other measurements from that area show frequent maximum subsidence rates between $-20 \mathrm{~mm} /$ year and $-268 \mathrm{~mm} /$ year. Considering the whole doline surface, the average subsidence rates in the same area vary between $-1.2 \mathrm{~mm} /$ year and $-80.6 \mathrm{~mm} /$ year, with accelerations of $0.3-0.7 \mathrm{~mm} /$ day [26]. Another example is the mean accumulated subsidence in Zuera (Zaragoza): $22 \mathrm{~mm} /$ year [27].

\subsection{Current and Future Situation}

These low rates of subsidence during the Holocene are somewhat confirmed today by the low frequency of karstified areas detected by geophysical methods. Possible areas of karstified residues, soft patches, or anomalous alluvial fills in former hollows only represent between $5 \%$ and $12 \%$ of the hidden zone beneath the alluvium. They are smaller than $20 \times 20 \mathrm{~m}$ in size and less than $20 \mathrm{~m}$ deep. The scarcity or absence of hypersoluble minerals may have contributed to this.

This gives us an idea of the low probability of finding these types of soft clayey masses or anomalous thicknesses in the substratum of the rest of the alluvium, and greater attention must be paid in future foundation projects.

On the other hand, the possibility of future land use changes in general, or water table variations of a certain amplitude in particular, may increase the risk factors in the gypsiferous substratum under alluvial clayey alluvial cover, and have to be considered in order to zone its potential hazard [14,28-31]. In our case, the opposite is expected: apart from the fact that the area has a small exposure to the karst hazard and is very localized in the fault zone, the excavation of a drainage ditch along the entire length of the development will further reduce the dissolution processes in the future. In fact, during sewerage works, it was necessary to lower the water table in the clayey aquiclude of the cover. For this purpose, a herringbone shaped trench of about $2 \mathrm{~km}$ in total length and up to $4 \mathrm{~m}$ deep was dug in 2019-2020, covering a large part of the development [10]. The flow drained by this ditch does not normally exceed $2 \mathrm{~L} / \mathrm{s}$, although recently, following the recharge due to the "Filomena" snowfall in January 2021, the flow evacuated by the ditch temporarily increased to $5 \mathrm{~L} / \mathrm{s}$. This effective subsurface drainage system reduces the inflow of undersaturated water to the gypsiferous clay system below, thus inhibiting karstification. The piezometric control network implemented will be used, in any case, to monitor possible alterations due to recharge from garden irrigation and leaks in the sewerage or water supply network. In the sinkhole area where a future road is planned (approximately $120 \times 120 \mathrm{~m}$ in size), work has begun to remove the alluvial substrate (present at a depth of around $2.5 \mathrm{~m}$ ). Subsequently, a rock fill will be built due to the presence of phreatic water, to be completed by placing a geotextile confining layer that will allow the embankment to be built in optimum conditions. The sinkhole on the eastern side is intended to be made into a green area with a small pond, so technical solutions with complementary works were not considered due to the unforeseeable risk situation. However, a detailed study was carried out to rule out the possible problems arising from the appearance of soluble salts or high subsidence rates. 


\section{Conclusions}

During the last decades, sinkhole hazards and associated risks have increased in many inhabited areas (e.g., $[14,18])$. There is an emerging trend in many karst regions to incorporate scientific knowledge of sinkholes into hazard prevention in land use planning (e.g., [1,32]). However, this knowledge transfer has not yet been sufficiently extended to planners and managers, which would avoid significant economic losses [17] and lead toward sustainability in the urban world.

Thanks to the application of different combined methods, it has been possible to determine that the small subsidence basin studied corresponds to the most active sector of a large depression formed by underlying karstification during the Quaternary. This clay-covered doline has been produced by slow flexural subsidence due to the removal of the bedrock and cover by dissolution of the interstratified layers of gypsum rich clays. It conforms to a fault and axis of an atectonic syncline that has concentrated the dissolving subsurface flow, accentuating the underlying karstification and topographic subsidence until the formation of a microlake basin during the Pleistocene. The karstification progressively exaggerates the syncline, and in a sector of the fault and bottom of the syncline there is collapse. As we can see, the dissolution is the cause of the syncline, and the syncline is the cause of the concentration of the flow: these have a cause and effect relationship with each other over time. The result is that the basin or doline filled with the alluvial formations of the Holocene age, mainly, in which there is groundwater discharge and the mouth of a stream ("Los Ahijones"), together with two natural watercourses.

The current average decrease could be evaluated at about $0.4 \mathrm{~mm} /$ year and concerns the alluvial zone, and the maximum is $1.4 \mathrm{~mm} /$ year in the fault zone. The possible karstified areas, karstified residues, soft patches, and anomalous alluvial fills in former hollows only represent between $5 \%$ and $12 \%$ of the hidden area beneath the alluvium. They have dimensions of less than $20 \times 20 \mathrm{~m}$ and depths of less than $20 \mathrm{~m}$. In the future, no acceleration in dissolution is expected because the flow will be substantially reduced by the draining action of a drainage ditch in the process of urbanization, and because there are no significant quantities of highly soluble mineral species.

The urbanization works, which are in full progress, are undertaking complementary measures aimed at the stability of the road by removing and cleaning up the alluvial deposits studied.

In those areas where road infrastructure is to be developed on the alluvial areas, during the execution of the urbanization works, constructive measures are being considered consisting of the complete removal of the alluvial material (whose depths detected in the road have not been greater than $5 \mathrm{~m}$ ), to subsequently execute a gradual embankment with reinforced geotextile protection. This construction procedure has allowed us to work in a wet area and guarantees the good mechanical behavior of the upper embankment.

In the case of the only area where a road structure must be implemented, the foundation avoids karst fillings and will be piloted, thus guaranteeing stability and functionality. To this end, geotechnical soundings will be taken at the site where the foundation piles are to be driven to guarantee the exact depth of the stable support stratum at the tip of the pile.

The area most affected by the aforementioned subsidence refers to the area designated by the territorial planning as an urban park, where there are no relevant infrastructures that need to be treated with special construction procedures.

Author Contributions: Conceptualization, E.S.P.; methodology, E.S.P.; writing-original draft preparation, E.S.P.; writing-review and editing, E.S.P.; supervision, C.S.R.; funding acquisition, C.S.R. Both authors have read and agreed to the published version of the manuscript.

Funding: This work was funded by two research agreements with the Compensation Board Los Ahijones and the Agustín de Betancourt Foundation ("Estudio geológico de detalle para la identificación del aluvial del arroyo de Los Ahijones dentro de la urbanización UZPp.02.03 Desarrollo del Este Los Ahijones Distrito 19. Vicálvaro (Madrid)").

Institutional Review Board Statement: Not applicable. 
Informed Consent Statement: Not applicable.

Data Availability Statement: Data available in a publicly accessible repository.

Acknowledgments: Ángel Granda Sanz (IGT) is thanked for carrying out the geophysical survey and for his help in the interpretation of the results. The authors express their sincere thanks to the experts who participated in this research: Felix Escolano (Universidad Politécnica de Madrid) and Ildefonso Reyes (Laboratorio CEYGE, SL), the latter with the drilling of the boreholes. The authors would also like to thank Álvaro Sanz de Ojeda, from the Mining School (Madrid), for his computer support and field work. We also thank the three anonymous reviewers who have contributed to improve this work.

Conflicts of Interest: The authors declare no conflict of interest.

\section{References}

1. Mancebo, J.A.; Sanz, E.; Menéndez-Pidal, I. Karstología de Terrenos Salinos Aplicada a la Ingeniería Civil; Editorial Garceta: Madrid, Spain, 2014.

2. Cooper, A.H.; Waltham, A.C. Subsidence caused by gypsum dissolution at Ripon, North Yorkshire. Q. J. Eng. Geol. 1999, 32, 305-310. [CrossRef]

3. Gutiérrez, F.; Cooper, A.H.; Johnson, K.S. Identification, prediction and mitigation of sinkhole hazards in evaporite karst areas. Environ. Geol. 2008, 53, 1007-1022. [CrossRef]

4. Guerrero, J.; Gutiérrez, F.; Lucha, P. Flood, dissolution subsidence and landslide hazards, damages and mitigation structures in Cadrete village. Rev. Cuatern. Geomorfol. 2005, 19, 63-82.

5. Carbonel, D.; Rodríguez, V.; Gutiérrez, F.; McCalpin, J.P.; Linares, R.; Roqué, C.; Zarroca, M.; Guerrero, J.; Sasowsky, I. Evaluation of trenching, ground penetrating radar (GPR) and electrical resistivity tomography (ERT) for sinkhole characterization. Earth Surf. Process. Landf. 2014, 39, 214-227. Available online: http:/ / refhub.elsevier.com/S0013-7952(17)31104-3/rf0030 (accessed on 7 July 2021). [CrossRef]

6. Fabregat, I.; Gutiérrez, F.; Roqué, C.; Comas, X.; Zarroca, M.; Carbonel, D.; Guerrero, J.; Linares, R. Reconstructing the internal structure and long-term evolution of hazardous sinkholes combining trenching, electrical resistivity imaging (ERI) and ground penetrating radar (GPR). Geomorphology 2017, 285, 287-304. Available online: http:/ / refhub.elsevier.com/S0013-7952(17)31104-3 /rf0045 (accessed on 7 July 2021). [CrossRef]

7. Sevil, J.; Gutiérrez, F.; Zarroca, M.; Desir, G.; Carbonel, D.; Guerrero, J.; Linares, R.; Roqué, C.; Fabregat, I. Sinkhole investigation in an urban area by trenching in combination with GPR, ERT and high precision leveling. Mantled evaporite karst of Zaragoza city, NE Spain. Eng. Geol. 2017, 231, 9-20. Available online: http:/ / refhub.elsevier.com/S0013-7952(17)31104-3/rf0155 (accessed on 7 July 2021). [CrossRef]

8. Escolano, F. Caracterización Geológico-Geotécnica de las Facies de Transición y Evaporíticas de la Cuenca de Madrid en el Interfluvio Manzanares-Jarama. Ph.D. Thesis, Universidad Complutense de Madrid, Madrid, Spain, 2005.

9. Sanz, E. Modelación Matemática del Flujo Subterráneo en el Acuicludo de la Urbanización Uzpp.02.03 Los Ahijones Distrito 19. Vicálvaro (Madrid) y su Entorno; Fundación Agustín de Betancourt Escuela Técnica Superior de Ingenieros de Caminos: Madrid, Spain, 2019; Informe inédito.

10. Sanz de Ojeda, J.; Sanz, E.; Elorza, F.J.; Riaguas, C.S.; Liaño, M.d.P. Simulation of Groundwater Flow in an Aquiclude for Designing a Drainage System during Urban Construction: A Case Study in Madrid, Spain. Sustainability 2021, 13, 1526. [CrossRef]

11. Bárez del Cueto, S.; Preysler, J.B.; Perez-Gonzalez, A.; Torres, C.; Rus Perez, I.; Vega de Miguel, J. Acheulian flint quarries in the Madrid Tertiary basin, central Iberian Peninsula: First data obtained from geoarchaeological studies. Quat. Int. 2016, 441, 329-348. [CrossRef]

12. Mochales, T.; Casas, A.M.; Pueyo, E.L.; Pueyo, O.; Román, M.T.; Pocoví, A.; Soriano, M.A.; Ansón, D. Detection of underground cavities by combining gravity, magnetic and ground penetrating radar surveys: A case study from the Zaragoza area (NE Spain). Environ. Geol. 2008, 53, 1067-1077. Available online: https://link.springer.com/content/pdf/10.1007/s00254-007-0733-7.pdf (accessed on 7 July 2021). [CrossRef]

13. Hoover, R.A. Geophysical choices for karst investigations. In Sinkholes and the Engineering and Environmental Impacts of Karst; Beck, B.F., Ed.; American Society of Civil Engineers: Reston, VA, USA, 2003; pp. 529-538. Available online: https://ascelibrary.org/ doi/abs/10.1061/40698(2003)48 (accessed on 7 July 2021).

14. Waltham, T.; Bell, F.; Culshaw, M. Sinkholes and Subsidence; Springer: Chichester, UK, 2005; p. 382. Available online: http: / /refhub.elsevier.com/S0013-7952(17)31104-3/rf0170 (accessed on 7 July 2021).

15. Patterson, D.; Davey, J.C.; Cooper, A.H.; Ferris, J.K. The application of microgravity geophysics in a phased investigation of dissolution subsidence at Ripon, Yorkshire. Q. J. Eng. Geol. 1995, 28, 83-94. [CrossRef]

16. Menéndez Pidal, I.; Mancebo Piqueras, J.A.; Sanz Pérez, E.; Sáenz Sanz, C. Influence of Hydrogeochemistry on Tunnel Drainage in Evaporitic Formations: El Regajal Tunnel Case Study (Aranjuez, Spain). Sustainability 2021, 13, 1505. [CrossRef] 
17. Gutiérrez, F.; Parise, M.; De Waele, J.; Jourde, H. A review on natural and human induced geohazards and impacts in karst. Earth Sci. Rev. 2014, 138, 61-88. Available online: http:/ / refhub.elsevier.com/S0013-7952(17)31104-3/rf0095 (accessed on 7 July 2021). [CrossRef]

18. Gutiérrez, F. Sinkhole hazards. In Oxford Research Encyclopedia of Natural Hazard Science; Oxford University Press: Oxford, UK, 2016; pp. 1-92. Available online: http:/ / refhub.elsevier.com/S0013-7952(17)31104-3/rf0080 (accessed on 7 July 2021).

19. Gutiérrez, F.; Zarroca, M.; Linares, R.; Roqué, C.; Carbonela, D.; Guerrero, J.; McCalpind, J.P.; Comase, X.; Cooper, A.H. Identifying the boundaries of sinkholes and subsidence areas via trenching and establishing setback distances. Eng. Geol. 2018, 233, 255-268. [CrossRef]

20. Kirkham, R.M.; Streufert, R.K.; Kunk, M.J.; Budahn, J.R.; Hudson, M.R.; Perry, W., Jr. Evaporite tectonism in the lower Roaring Fork River valley, west-central Colorado. In Late Cenozoic Evaporite Tectonism and Volcanism in West-Central Colorado; Kirkham, R.M., Scott, R.B., Judkins, W., Eds.; Geological Society of America special paper: Boulder, CO, USA, 2002; Volume 366, pp. 73-99.

21. Gutiérrez, F. Fenómenos de Subsidencia por Disolución de Formaciones Evaporíticas en las Fosas Neógenas de Teruel y Calatayud (Cordillera Ibérica). Ph.D. Thesis, University of Zaragoza, Zaragoza, Spain, 1998; p. 569. Available online: https: / / dialnet.unirioja.es / servlet/tesis?codigo=203256 (accessed on 7 July 2021).

22. Klimchouk, A. Dissolution and conversions of gypsum and anhydrite. In Spelogenesis. Evolution of Karst Aquifers; Klimchouk, A., Ford, D.C., Palmer, A.N., Dreybrodt, W., Eds.; National Speleological Society Inc.: Hunstville, AL, USA, $2002 ;$ pp. $160-168$.

23. Jeschke, A.A.; Vosbeck, K.; Dreybrodt, W. Surface controlled dissolution rates of gyppsum in aqueous solutions exhibit nonlinear dissolution kinetics. Geochim. Cosm. Acta 2001, 65, 27-34. [CrossRef]

24. Uscatescu, A. Splendor de lo cotidiano. Objetos dorados de una aldea medieval madrileña (Ermita Virgen de la Torre, VicálvaroVallecas). An. Hist. Arte 2014, 24, 559-575. [CrossRef]

25. Simón, J.L.; Soriano, M.A.; Arlegui, L.; Gracia, J.; Liesa, C.; y Pocoví, A. Space-time distribution of ancient and active alluvial karst subsidence. Examples from the central Ebro Basin, Spain. Environ. Geol. 2008, 53, 1057-1065. [CrossRef]

26. Desir, G.; Guerrero, J.; Gutiérrez, F.; Carbonell, D.; Merino, J.; Benito, A.; Fabregat, I.; Roqué, C.; Zarroca, M.; Linares, R. Monitorización de Dolinas Activas en el Entorno de Zaragoza Mediante Nivelación Geométrica de alta Precisión; Instituto Geológico y Minero de España: Madrid, Spain, 2016; pp. 603-613.

27. Ramón Pellejero, R. Análisis Cartográfico de Dolinas Activas en el Valle del Río Gállego y Medición de Tasas de Subsidencia. Trabajo de Fin de Grado de Geología; Universidad de Zaragoza: Zaragoza, Spain, 2019.

28. Soriano, M.A.; Simón, J.L.; Gracia, J.; y Salvador, T. Alluvial sinkholes over gypsum in the Ebro basin (Spain): Genesis and environmental impact. Hydrol. Sci. J. 1994, 39, 257-268. [CrossRef]

29. Soriano, M.A.; y Simón, J.L. Alluvial dolines in the central Ebro basin, Spain: A spatial and developmental hazard analysis. Geomorphology 1995, 11, 295-309. [CrossRef]

30. Galve, J.P.; Bonachea, J.; Remondo, J.; Gutiérrez, F.; Guerrero, J.; Lucha, P.; Cendrero, A.; Gutiérrez M y Sánchez, J.A. Development and validation of sinkhole susceptibility models in mantled karst settings. A case study from the Ebro valley evaporite karst (NE Spain). Eng. Geol. 2008, 99, 185-197. [CrossRef]

31. Sanz, E. El karst en yesos en Fuentes (Cuenca). Karst and Environment. In Proceedings of the Nerja Cave Foundation, Malaga, Spain, 15-17 September 2002; pp. 351-358.

32. Farrant, A.R.; Cooper, A.H. Karst geohazards in the UK: The use of digital data forhazard management. Q. J. Eng. Geol. Hydrogeol. 2008, 41, 339-356. Available online: http:/ / refhub.elsevier.com/S0013-7952(17)31104-3/rf0050 (accessed on 7 July 2021). [CrossRef] 